\title{
Crude Necator americanus worm extract diminishes pancreatic islets destruction in diabetic non-obese mice (NOD)
}

Teresiama Velikkakam ${ }^{\mathbf{1}}$; Bruna Garzedim de Araujo', Érica Alessandra Rocha Alves ${ }^{\mathbf{1}}$, Ricardo Toshio Fujiwara ${ }^{2}$, Lilian Lacerda Bueno ${ }^{2}$, Jacqueline Araújo Fiuza ${ }^{1}$, Soraya Gaze $^{1^{\#}}$.

${ }^{1}$ Cellular and Molecular Immunology Group. Rene Rachou Institute. Oswaldo Cruz Foundation - MG. Brazil.

${ }^{2}$ Immunology and Genomic of Parasites Laboratory. Department of Parasitology. Federal University of Minas Gerais. Brazil.

\section{${ }^{\#}$ Corresponding author}

Dr Soraya T. Gaze, PhD

Rene Rachou Institute

Oswaldo Cruz Foundation

Av Augusto de Lima 1715. Barro Preto.

Belo Horizonte. Minas Gerais. - MG

Brazil

Zip code: 30190-002. Brazil.

\begin{abstract}
Hygiene hypothesis dictates that the lack of microbial interaction during the first childhood increases the chance of developing autoimmune diseases due to not proper immune system maturation. Helminthes are known by their Th2 and modulatory immune response induction. Here, it was evaluated the influence of Necator americanus antigens during type 1 experimental mouse model (non-obese diabetic - NOD). Intraperitoneal injections for 18 weeks did not impair an inflammatory response, but induced a mixed Th1/Th2 response with presence of IL4 and IL10 from different sources. However, the induced immune response was not sufficient to decrease glucose levels but showed a change in the inflammatory infiltrate in the pancreas. It is necessary more refined studies to clarify the mechanisms of how Necator americanus could impair diabetes progression in mice.
\end{abstract}

Keywords: hygiene hypothesis, Necator americanus, diabetes type 1

Sponsorhip: CNPq and Fiocruz. 


\section{Introduction}

Diabetes melittus type 1 (DM1) is a disease characterized by pancreatic $\beta$ cell selective destruction due to an autoimmune response (KAHALY; HANSEN, 2016). Its pathogenesis has many components, and in humans involves dysfunction in 40 major histocompatibity complex loci (HLA) (ATKINSON, 2014). Environment elements, like diet and infections, have an important role in this disease progress since they affect the immune system, especially in genetic susceptible people (CLARK; KROGER; TISCH, 2017). In the majority of the cases, DM1 is latent and asymptomatic for several years. Clinical manifestations only appear if $60-90 \%$ of pancreatic $\beta$ cells are destroyed by the immune system and insulin production is not enough to control glucose levels in the blood (COPPIETERS; VON HERRATH, 2009).

It is known that the destruction of $\beta$ cells is mediated by T and B cells, NK cells and APCs infiltrated in the islets of Langerhans (RICHARDSON; MORGAN; FOULIS, 2014; ZÓKA; SOMOGYI; FIRNEISZ, 2012). Several studies have demonstrated that, during the progression of the disease, the activation of $\mathrm{T}$ regulatory (Treg) cells culminates with a modulatory response capable of stopping the $\beta$ cell autoantibodies production and autorreactive $\mathrm{T}$ cells effectiveness, evolving in a downmodulation in DM1 (ASKENASY, 2016; ATKINSON; EISENBARTH; MICHELS, 2014; CLARK; KROGER; TISCH, 2017; FERRETTI; LA CAVA, 2016).

Helminth infections are described as modulators of inflammatory responses due to their capacity of strong induction of Th2 and Treg immune responses (CANÇADO; FIUZA; DE PAIVA; LEMOS et al., 2011; MOTRAN; SILVANE; CHIAPELLO; THEUMER et al., 2018). Some studies have shown that DM1 in NOD mice may be ameliorated by helminthes. This property have been attributed to the fact that epitopes from helminthes were able to change the microenviroment of DM1 inflammation inducing Treg cells to produce IL-4, IL-10 and TGF- $\beta$ (BERBUDI; AJENDRA; WARDANI; HOERAUF et al., 2016; EGRO, 2013). Schistosoma mansoni antigens secreted by eggs were also able to reduce Treg cell proliferation, preventing DM1 in 4 weeks old NOD mice (ZACCONE; BURTON; MILLER; JONES et al., 2009). Other autoimmune diseases can also be moderated by helminthes infections in experimental models. Studies with autoimmune encephalomielitys (GRUDEN-MOVSESIJAN; ILIC; MOSTARICASTOJKOVIC; STOSIC-GRUJICIC et al., 2010), colitis (SMITH; MANGAN; WALSH; FALLON et al., 2007), sclerosis (FLEMING, 2013) and rheumatoid arthritis (OSADA; SHIMIZU; KUMAGAI; YAMADA et al., 2009) also showed that helminthes and/or their products were able to prevent or suppress autoimmune diseases. However, it is not clear which helminthes can ameliorate and how they act in experimental DM1. Thus, this study evaluated the effect of crude antigens from adult Necator americanus in NOD mice model of DM1. The therapeutic properties of this parasite have been widely investigated in other autoimmune diseases, as well as celiac disease in humans.

\section{Methods}


Mice - Non-obese diabetic (NOD) female mice with 4 weeks obtained from Science and Technology in Biomodels Institute (Fiocruz) were tested negative for helminthes and protozoa. They were kept for two weeks in the same environmental conditions used in the experimental protocol for adaptation. Animals were kept in micro-isolater racks during all experimental period All the manipulation was under a sterile environment. Mice were divided in control (PBS) and AdEx (treatment) with 15 mice in each study group . All experimental protocols were reviewed and approved by Federal University of Minas Gerais Ethical Committee (license number 389/2012).

Necator americanus crude extract (AdEx) - Hamsters were infected, via gavage, with 100 Necator americanus infective larvae stage. At day 42 post infection, animals were euthanized and adult worms were removed from intestine, washed with PBS plus antibiotics and sonicated in PBS. The solution was centrifuged at $500 \mathrm{xg}$ and supernatant was filtered at $0.22 \mu \mathrm{M}$. Protein concentration was measured using microBCA kit accoding to manufature's protocol (Pierce). The antigen was kept at $80^{\circ} \mathrm{C}$ until used. Antigens from $N$. americanus were kindly donated by Dr Ricardo Fujiwara (UFMG).

Experimental design - NOD female mice (6 weeks old) were individually identified and monitored for 18 weeks. During this period, groups received, 3 times a week, 100 $\mu \mathrm{L}$ of PBS (control) or $15 \mu \mathrm{g}$ AdEx per dose by intraperitoneal injection. Once a week, tail blood samples were collected to manufacture blood smear slides and to measure glicemia. At the end of 18 weeks treatment, mice were euthanized with overdose of xylazine and ketamine injected in the peritoneal cavity. Blood, pancreas and spleen were collected to measure immunological parameters.

Blood glicemia measurement - Once a week, tail blood was placed in a tape to measure glicemia (ACCU-Check Active, Roche). All collections were done around the same hour in the day to decrease variation. Blood glicemia was considered non-fasten since the food was available all the time. Values were expressed in $\mathrm{mg} / \mathrm{dL}$ and levels higher than $200 \mathrm{mg} / \mathrm{dL}$ were considered abnormal.

Blood smear slides - Once a week, a drop was collected from the tail to make blood smear slides. Then, blood cells were stained with hematology staining kit (Laborclin), in accordance with manufacturer's instructions. Cells were analyzed under optical microscopy and the relative number (\%) of circulating eosinophils, lymphocytes, neutrophils, basophils and monocytes was assessed by counting one hundred leukocytes, following Vanilda and Nascimento protocol (Vanilda and Nascimento, 2014).

Histological analysis - Pancreas was carefully removed, identified and placed in $4 \%$ formalin buffer for fixation. Briefly, $\mathrm{H} \& \mathrm{E}$ staining was performed on $4-\mu \mathrm{m}$ sequential sections of formalin-fixed, paraffin-embedded after placed in sylanized glass 
slides using hematoxylin and eosin (ALVARENGA; SILVA; FIUZA; GAZE et al., 2018). Slides were analysed using optical microscope and the most preserved cut was selected to count and analyze all the pancreatic islets per animal. Islets were classified according to morphology and inflammatory infiltrate: without insulitis; moderate insulitis, peri-insulitis, severe insulitis, according described before (UKAH; CATTINROY; CHEN; MILLER et al., 2017)

Flow cytometry - After euthanasia, spleens were collected and macerated in PBS through a $70 \mu \mathrm{M}$ cell strainer (BD Falcon). Cell suspension was centrifuged at $300 \mathrm{xg}$ and supernatant was discarded. Red blood cells were lysed with sterile distilled water, and leucocytes were centrifuged at $300 \mathrm{xg}$, ressupended and counted in RPMI1640 (Gibco) suplemented with 10\% heat inactivated fetal bovine serum (Cultilab) with gentamicina $40 \mu \mathrm{g} / \mathrm{mL}$ (Sigma-Aldrich). Leucocytes at 1x106 were then kept in short period culture $(4 \mathrm{~h})$ with Brefeldin A $(10 \mu \mathrm{g})$ (Sigma-Aldrich), $5 \mu \mathrm{g}$ PMA (SigmaAldrich) and $50 \mu \mathrm{g}$ Inomycin (Sigma-Aldrich). Later, cells were centrifuged, Fc receptor was blocked according to manufacture's protocol (BD Biosciences) and stained with surface and cytokines antibodies according Fiuza et al., 2015 (Vaccine 2015 (33) 208-288). Antibodies (eBiosciences) used were: CD3 FITC(clone 145-2C11), CD4 PerCP-Cy5.5(clone RM4-4), CD8 BV421(clone 53-6.7), CD62L BV605(clone MEL14), CD25 BV510(clone PC61), Cells were then fixed, permeabilized and stained for the cytokines IL-4(clone 11B11), IL-12p40(clone C15.6), IFN- $\gamma$ (clone XMG1.2), TNF$\alpha$ (clone MP6-XT22), IL-5 (clone TRFK5), IL-17A (clone TC11-18H10.1) and IL-10 (clone JES5-16E3), all PE. Data for 1×105 lymphocytes (gated by forward and side scatter) were acquired with a FACSFortessa flow cytometer and analyzed using FlowJo software (both from BD Biosciences). Isotype controls were used in all experiments.

Nitric oxide measurement - Nitric oxide was measured in the splenocytes 4 h culture's supernatant and in the serum collected after 18 weeks treatment. It was used Griess indirect reaction according to (GRANGER; TAINTOR; BOOCKVAR; HIBBS, 1996). Plates were read in Spectra-Max® Plus384 microplate reader (Molecular Devices) at $540 \mathrm{~nm}$. Sample concentration was interpolated in a standard curve, using the sample diluents, and showed as $\mu \mathrm{g} / \mathrm{mL}$. 
Serum cytokine concentration - Blood was centrifuged at 10,000 xg and sera were obtained and stored at $-80^{\circ} \mathrm{C}$ until individual testing for cytokine levels. Sera were thawed only once and serum levels of IL-17A, TNF- $\alpha$, IL-6, IFN- $\alpha$, IL-2, IL-4 and IL10 were quantified using the BD Cytometric Bead Array (CBA) Mouse Th1/Th2/Th17 Cytokine kit (BD Biosciences) following the manufacturer's instructions. In addition, serum levels of IL-6, IL-10, MCP-1, IFN- $\gamma$, TNF- $\alpha$ e IL-12p70 were measured using BD Cytometric Bead Array (CBA) Mouse Inflammation kit (BD Bioscienses) according to manufecturer's protocol. Data were acquired with FACSVerse (BD Biosciences) and analyzed using Flowjo 6.0 (BD Biosciences). Liophilized cytokines were used as standard and values were expressed/showed as as $\mathrm{pg} / \mathrm{mL}$. All values below detection limit were considered zero.

Real-time quantitative PCR - Fresh prepared splenocytes were centrifuged and supernatant was discarded. Trizol (Invitrogen) solution was added and RNA extraction was prepared according to manufacturer's protocol and concentration measured by Nanodrop (Thermo Fisher). After treatment of the RNA with DNAse (RQI Promega,),cDNA was synthesizedusing SuperScript II (Invitrogen). For real-time PCR, 10ng of cDNA was used per reaction with Syber Green (Promega). All the primers (described in Table 1) were designed and optimized. The experiments were perfomed using Step One Plus equipment and results analysed by Step One Software (Applied Biosystems). Results are expressed by $2^{\wedge}$ (CT test- CT control), and beta-actin was chosen as housekeeping gene.

Table 1: Primers designed for each tested gene used in real-time PCR.

\begin{tabular}{l|c|c|c}
\hline \multicolumn{1}{c|}{ Gene } & Foward & Reverse & Amplicon \\
\hline$\beta$ - $a c t$ & TTGTTACCAACTGGGACGAC & ACGGTTGGCCTTAGGGTT & 125 \\
$i f n-\gamma$ & CGGCTGACCTAGAGAAGACA & GTAACAGCCAGAAACAGCCA & 160 \\
$t g f-\beta$ & TTTAGGAAGGACCTGGGTTG & CTTGCGACCCACGTAGTAGA & 216 \\
$i l-12 a$ & CTTTGATGATGACCCTGTGC & GCAGAGTCTCGCCATTATGA & 183 \\
$i l-5$ & GCTGGCCTCAAACTGGTAAT & TGGTAACATGCACAAAGCCT & 152 \\
$i l-21$ & AAATGCCCTTCCTGTGATTC & CTGCATTCGTGAGCGTCTAT & 191 \\
arginase & GGTTCTGGGAGGCCTATCTT & AAGCAAGCCAAGGTTAAAGC & 171 \\
retlna & GTCCTGGAACCTTTCCTGAG & AGCTGGATTGGCAAGAAGTT & 180 \\
$i l-10$ & TAAGGGTTACTTGGGTTGCC & TCACTCTTCACCTGCTCCAC & 213 \\
\hline
\end{tabular}

Statistical analysis - $\mathrm{T}$ test with Holm-Sidak post-test was used for multicomparisons. Also, two non-parametric tests Mann-Whitney test and Spearman 
correlation, according to analyzed data. Statistical significance was considered if $\mathrm{p}$ value $\leq 0.05$. All data was analyzed using GraphPad Prism 6.0 software (GraphPad).

\section{Results}

Blood glicemia was not affected by AdEx treatment - Blood glucose levels were measured weekly, in the morning, for 18 weeks. During all experimental period, there was no difference in the circulating levels of glucose between AdEx-treated and placebo groups show (Figure 1A). During the 18 weeks treatment, four animals per control group and three mice per AdEx group showed levels above $600 \mathrm{mg} / \mathrm{dL}$ and all died before the next measurement. Since all NOD mice were individually identified, glucose levels were also analyzed considering the first measurement (week 1). Results were plotted in heatmap (Figure 1B), where gray indicates lower variation and red higher variation compared to the first week of treatment. As demonstrated in the figure 1B, AdEx-treated group showed a tendency to have lower variation in the blood glucose levels than PBS group (Figure 1B).

NOD mice presented decreased severity of insulitis after AdEx treatment- Pancreas from mice were evaluated by optical microscopy after H\&E staining. The severity of insulitis was analyzed by the_total number of Langerhans islets and size of inflammation around them. When data was analyzed, AdEx group showed higher number of Langerhans islets than PBS group (Figure 2A). Moreover, Langerhans islets were larger than those found in the control group. The results also demonstrated that mice treated with AdEx showed $42.3 \%$ of islets without insulitis $11.5 \%$ with periinsulitis, $15.4 \%$ with moderate insulitis and $30.8 \%$ com severe insulitis. On the other hand, while animals treated with PBS showed $29.7 \%$ of islets without insulitis, $18.5 \%$ with periinsulitis, $11.1 \%$ with moderate insulitis, and $40.7 \%$ with severe insulitis (Figure 2B), indicating a decrease of the inflammatory response in the AdEX-treated group.

AdEx treatment induces an increase of circulating eosinophils - AdEx injections increased the relative number of circulating eosinophils. This increase was significant as early as second week of treatment and was kept elevated through the whole treatment compared to the PBS control group (Figure 3). The relative number of lymphocytes was also increased in the AdEx group (data not shown). The other cell subtypes analyzed, including neutrophils, mastocytes, basophils and monocytes, showed no difference between both analyzed groups.

A mixed immune response profile was observed after AdEx treatment - The profile of cytokines induced by AdEx treatment was evaluated in two compartments: Sera and splenocytes. In the sera from NOD mice, the AdEx treatment induced an increase of IL-2 ( $\mathrm{p}=0.0138$; Figure 4A), IFN- $\gamma(\mathrm{p}=0.0072$; Figure 4B), IL-12 ( $\mathrm{p}=0.0138$; Figure 4C) and IL-6 ( $\mathrm{p}=0.0099$; Figure 4D), all considered inflammatory cytokines, 
compared to the control group. In addition, AdEx-treated mice presented increased serum levels of IL-4 ( $p=0.0009$; Figure 4E) and IL-10 ( $p=0.0138$; Figure 4F) compared to the PBS-treated animals, showing that the AdEx treatment induced a mixed profile of circulating cytokines. Since we have observed increased production of modulatory cytokines in sera from AdEx-treated mice, we also analyzed short cultured splenocytes, in order to know which cells were producing those cytokines. Interesting, our results demonstrated that, after 18 weeks treatment, the AdEx group have increased IL-4 production by $\mathrm{CD}^{+}(\mathrm{p}=0.0086$; figure $5 \mathrm{~A})$ and $\mathrm{CD}^{+}(\mathrm{p}=0.0129$; figure $5 \mathrm{~B}) \mathrm{T}$ cells. . In addition, AdEx mice presented higher IL-10 production, not only by $\mathrm{CD}^{+}(\mathrm{p}=0.0086$; figure $5 \mathrm{C}$ ) and $\mathrm{CD}^{+}(\mathrm{p}=0.0086$; figure $5 \mathrm{D}) \mathrm{T}$ cells, as well as by macrophages $(\mathrm{p}=0.0086$; figure $5 \mathrm{~F}$ ), compared to the PBS group. Furthermore, in the splenocytes culture from AdEx group, the production of IL-10 was also higher by the subpopulation of $\mathrm{CD}^{+} \mathrm{T}$ cells expressing CD25 $\left(\mathrm{CD} 4^{+} \mathrm{CD} 25^{+}\right)$than in the culture from PBS control group ( $\mathrm{p}=0.031$, figure $5 \mathrm{E}$ ). Taken together, results from splenocytes culture showed that treatment with ADEX increased the production of modulatory cytokines by splenic leukocytes. Other cytokines measured according to described before did not show statistical differences between analyzed groups.

Levels of mRNA related with inflammatory and modulatory immunological profiles were evaluated (IFN- $\gamma$, IL-12a, IL-5, IL-21, Retnla, Arginase, TGF- $\beta$ and IL-10) were analyzed in splenocytes by qPCR. RETNLA (Fizz1) showed higher expression in AdEx group ( $\mathrm{p}=0.0116$ ) compared to control (Figure 6A). However, the expression of other regulatory genes, as Arginase, TGF- $\beta$ and IL-10, was lower in AdEx mice compared to control group ( $\mathrm{p}=0.0117, \mathrm{p}=0.0369$ and $\mathrm{p}=0.0113$, respectively) (Figure 6B, C and D, respectively). No statiscal differences were observed when analyzing the expression of IFN- $\gamma$, IL-12a, IL-5, IL-21 (data not shown).

AdEx treatment induces decrease of Nitric Oxide - The levels of NO were analyzed in sera and culture supernatant from splenocytes by Griess reaction. In both, the treatment with AdEx for 18 weeks induced lower levels of nitric oxide when compared to control PBS group (sera, $\mathrm{p}=0.002$ and supernatant, $\mathrm{p}=0.003$ ) (Figures 7A and B), showing that AdEx injection is influencing free radicals production in NOD mice..

Higher levels of glucose is negative correlated to levels of modulatory cytokines. Correlations were made between levels of glucose and production of IL-4 and IL-10 by $\mathrm{CD}^{+}$and $\mathrm{CD}^{+} \mathrm{T}$ cells. After 18 weeks of treatment with AdEx, mice that presented higher levels of glucose showed a decrease of IL4CD4 ( $p=0.0183, r=0.6714$; figure 8A), IL4CD8 ( $\mathrm{p}=0.0174, \mathrm{r}=0.6749$; figure 8B) and IL10CD4 $(\mathrm{p}=0.00264, \mathrm{r}=0.6797$; figure $8 \mathrm{C})$, being correlated negatively.

\section{Discussion}


The use of helminthic parasites as therapeutic tools for chronic diseases has been studied for many groups (CANÇADO; FIUZA; DE PAIVA; LEMOS et al., 2011; CROESE; O'NEIL; MASSON; COOKE et al., 2006; ELLIOTT; LI; BLUM; METWALI et al., 2003; ELLIOTT; SETIAWAN; METWALI; BLUM et al., 2004; ELLIOTT; URBAN JF; ARGO; WEINSTOCK, 2000; HÜBNER; SHI; TORRERO; MUELLER et al., 2012; IMAI; TEZUKA; FUJITA, 2001; KHAN; BLENNERHASSET; VARGHESE; CHOWDHURY et al., 2002; LIU; SUNDAR; MISHRA; MOUSAVI et al., 2009; REARDON; SANCHEZ; HOGABOAM; MCKAY, 2001; SAUNDERS; RAINE; COOKE; LAWRENCE, 2007; SUMMERS, R. W.; ELLIOTT, D. E.; URBAN, J. F.; THOMPSON, R. et al., 2005; SUMMERS, R. W.; ELLIOTT, D. E.; URBAN, J. F.; THOMPSON, R. A. et al., 2005; SUTTON; ZHAO; MADDEN; ELFREY et al., 2008). Particularly for DM1, the use of pathogens or pathogen-derived products have shown to modulate autoimmune diabetes in the NOD mice (HARN; MCDONALD; ATOCHINA; DA'DARA, 2009; HÜBNER; SHI; TORRERO; MUELLER et al., 2012; HÜBNER; STOCKER; MITRE, 2009; IMAI; TEZUKA; FUJITA, 2001; LIU; SUNDAR; MISHRA; MOUSAVI et al., 2009; SAUNDERS; RAINE; COOKE; LAWRENCE, 2007; SUTTON; ZHAO; MADDEN; ELFREY et al., 2008; ZACCONE; FEHÉRVÁRI; JONES; SIDOBRE et al., 2003). The present work also demonstrated important implications in NOD mice, as a mixed Th1/Th2 response and the decrease of damage in the pancreas. It is important to note that in our study, mice showed lower incidence of diabetes than previously reported (Liu et al., 2009). It is known that the age is one important factor to influence the normal glucose levels. In NOD mice, there are evidences that diabetes may develop as late as 30 weeks of life (KAMINITZ; MIZRAHI; ASKENASY, 2014). Unfortunately, at the end of the experimental period, NOD mice were 24 weeks old because AdEx was available to perform treatment just for 18 weeks.

When mice were individually compared, there is a tendency of AdEx treatment to keep glucose levels near the week 0 levels. Interestingly, the glucose blood levels corroborate the inflammation found in the pancreas. Histology analyses showed that the pancreatic islet destruction was not different in numbers from AdEx to control group. Thus, could be a reason that diabetes had lower rates in this study. However, the AdEx treatment seems to influence the inflammatory infiltrate in the pancreas since $42 \%$ of the islets had no insulitis in treat group compared to $29.7 \%$ in control group.

It has been shown that $N$. americanus infection can induce a strong Th2 response, but Th1 component is also present (GEIGER; CALDAS; MC GLONE; CAMPIAZEVEDO et al., 2007). AdEx used in this study is composed of proteins from whole adult worms, males and females, and could explain the mixed response observed. Eosinophils have been shown to play an important effector role in helminth infections. They could immunopolarize the response (WEBB; TAIT WOJNO, 2017), inducing preferably Th2 response through releasing mediators like Indoleamine 2,3-dioxygenase and Eosinophil-derived neurotoxin (SPENCER; WELLER, 2010). Since there was an increase of eosinophils in early weeks of injection, they could contribute to favor a 
strong Th2 immune response, as observed, in the presence of $N$. americanus antigens and could be one of the mechanisms to decrease damage in the pancreas.

Splenocytes were also affected by AdEx treatment demonstrating the capacity to influence several immune sites. After 18 weeks treatment, $\mathrm{CD}^{+}$and $\mathrm{CD} 8^{+} \mathrm{T}$ cells producing IL-4 and IL-10 showed an increased numbers in the spleen compared to control placebo group. Other studies had shown that helminthes can stimulate Treg cells and other types inducing IL-10 and IL-4 production, and this could ameliorate inflammation caused by Th1 and Th17 (GAZE; DRIGUEZ; PEARSON; MENDES et al., 2014; MCSORLEY; HEWITSON; MAIZELS, 2013; WEBB; TAIT WOJNO, 2017). This is particularly important since NOD mice have shown lymphopenia, especially for $\mathrm{CD}^{+}$and Treg cells (DEJACO; DUFTNER; GRUBECKLOEBENSTEIN; SCHIRMER, 2006; KING; ILIC; KOELSCH; SARVETNICK, 2004). It was also described a lower IL-4 intrinsic production by NOD mice (AOKI; BORCHERS; RIDGWAY; KEEN et al., 2005; DELOVITCH; SINGH, 1997). Thus, AdEx treatment increased the IL-4 and IL-10 not only by splenocytes but also blood circulating cytokines, another way to help controlling the inflammation in the pancreas.

Moreover, IL-12, IL-2 and IL-6 levels were increased in treated mice sera. Nevertheless, how those cytokines balance in different compartments are interfering in the DM1 pathology still needs a deeper understanding. The corroboration that the steady state of AdEx treatment, even if it is only for 18 weeks, is an attempt of controlling inflammation, also demonstrated by lower levels of nitric oxide production in treated group compared to control group. This could be a result of a possible alternative macrophage induction by AdEx producing IL-10. Alternative activated macrophages express Arginase-1 inducing L-ornitin production and are involved in wound healing (REYES; TERRAZAS, 2007). On the other hand, classic macrophages convert arginin in nitric oxide causing lesion by respiratory burst and $\beta$ cells killing (REYES; TERRAZAS, 2007). This could be one of the factors involved in the pancreatic islets preservation observed in AdEx group. The induced mixed profile was also shown by mRNA levels. Although Arginase mRNA was decreased in AdEx treated group, while FIZZ1 (Retnla) was increased compared to control group. FIZZ1 is a molecule expressed by alternative macrophages and is also involved in wound healing (ANTHONY; RUTITZKY; URBAN; STADECKER et al., 2007). Other studies also demonstrate that helminthes induce higher levels of FIZZ1 in mice (ANTHONY; URBAN; ALEM; HAMED et al., 2006; NAIR; GALLAGHER; TAYLOR; LOKE et al., 2005).

An association between AdEx treatment and diabetes amelioration were demonstrated by correlations between blood glucose levels and $\mathrm{CD} 4^{+}$and $\mathrm{CD} 8^{+} \mathrm{T}$ cells producing IL4 and IL-10. Those negative correlations suggest a potential effect of AdEx to reduce the damage caused by diabetes type 1 in mice. Thus, this study corroborates the hypothesis of helminthes antigens can potentially modulate and modify the immune response to benefit mice affected by DM1. Other studies with infections or antigen administration using Schistosoma mansoni, Taenia crassiceps, Heligmosomoides 
polygyrus, Trichinella spiralis ou Strongyloides venezuelensis showed that helminthes parasites prevented or inhibited DM1 in NOD mice (AJENDRA; BERBUDI; HOERAUF; HÜBNER, 2016). However, this positive effect only happened if antigen administration or infection started before insulitis establishment, usually around 4 weeks old in NOD mice (BERBUDI; AJENDRA; WARDANI; HOERAUF et al., 2016).

In conclusion, this study showed the potential therapeutic use of Necator americanus antigens to prevent DM1 progression by decreasing $\beta$ cell destruction. This study supports the need for further analysis aiming at elucidating the helminth-induced mechanisms in DM1.

\section{Acknowledges}

This project had financial support from Conselho Nacional de Pesquisas (CNPq) Universal grant number 444060/2014-6 and Rene Rachou Institute-Fiocruz MG. TV, BGA had scholarship, and JAF had fellowship, from CNPq. RTF and LLB have career fellowship from CNPq. Data and results provided by this manuscript are not plagiarism and were not published anywhere before here. The authors also thank the flow cytometry platform of the Fiocruz Program for the Technological Development Tools for Health (PDTIS). We are very thankful for the help of Dr Marcelo Antônio Pascoal Xavier.

\section{Author's contribution}

TV, BGA, EARA, JAF and SG participated in all experiments and analysis. TV, EARA, RTJ, LLB, JAF and SG wrote the manuscript. JAF, EARA and SG designed experiments. RTJ and LLB provided crude $N$. americanus extract.

\section{Legends}

Figure 1 - Blood glucose levels distribution after 18 weeks of AdEx treatment. (A) Blood glucose levels $(\mathrm{mg} / \mathrm{dL})$ in mice from treated (AdEx) and control (PBS) groups from week 0 to 18. Dashed line indicates level of permanent glycemia and gray area normal non-fasting glycemia levels according to (LEITER; PROCHAZKA; COLEMAN, 1987) (B) Heat map of glycemia levels per week per group. Lower level considered 140mg/dL (gray) and upper level $400 \mathrm{mg} / \mathrm{dL}$ (red). Empty spots indicated lost of measurement since mice did not survive.

Figure 2 - Evaluation of inflammatory infiltrate in Langerhans islets in NOD mice treated with AdEx. Total number (A) and percentage (B) of Langerhans islets presenting or not inflammatory infiltrate.. From bottom to top: green - no insulitis, yellow - perinsulitis, orange - moderate insulitis, red - severe insulitis. 
Figure 3 -Percentage of eosinophils in the blood circulation. Square - control group, circle AdEx group. Data presented as mean \pm SEM.

Figure 4 - Serum levels of cytokines in NOD mice treated or not with AdEx. . (A) IL-2; (B) IFN- $\gamma$; (C) IL-12; (D) IL-6; (E) IL-4; (F) IL-10. Red circles - control (PBS) group. Green square - treated (AdEx) group. Statistical analysis was performed using unpaired $\mathrm{T}$ test. Data presented as mean \pm SEM. Dashed line indicates detectable levels according to manufacture's protocol.

Figure 5 -Evaluation of the cytokine levels in the culture supernatant of splenocytes from NOD mice treated or not with AdEx. (A) IL4CD4; (B) IL-4CD8; (C) IL10CD4; (D) IL10CD8; (E) CD4CD25IL-10; (F) F4/80IL-10. Red circles control (PBS) group. Green square - treated (AdEx) group. Statistical analysis was performed using unpaired $T$ test. Data presented as mean \pm SEM.

Figure 6 - Fresh spleen cell mRNA expression evaluation. (A) RETNLA (FIZZ-1); (B) Arginase; (C) TGF; (D) IL10. Red circles - control (PBS) group. Green square treated (AdEx) group. Statistical analysis was performed using unpaired T test. Data presented as mean \pm SEM.

Figure 7 - Nitric oxide production evaluation. (A) Sera; (B) Supernatant of 4 h spleen cell culture. Red circles - control (PBS) group. Green square - treated (AdEx) group. Statistical analysis was performed using unpaired $\mathrm{T}$ test. Data presented as mean \pm SEM.

Figure 8 - Correlation between $4 \mathrm{~h}$ culture of spleen cell population and glucose level at week 18. (A) IL4CD4; (B) IL-4CD8; (C) IL10CD4 versus glucose level at week 18 in treated (AdEx) group (green square). Green line correlation. Dashed line: $95 \%$ of distribution.

\section{References}

AJENDRA, J.; BERBUDI, A.; HOERAUF, A.; HÜBNER, M. P. Combination of worm antigen and proinsulin prevents type 1 diabetes in NOD mice after the onset of insulitis. Clin Immunol, 164, p. 119-122, Feb 2016.

ALVARENGA, D. L. R.; SILVA, A. H. D. S.; FIUZA, J. A.; GAZE, S. T. et al. HIV aspartyl protease inhibitors modify the percentage of activated leukocytes, as well as serum levels of IL-17A and NO during experimental leishmaniasis. Int Immunopharmacol, 60, p. 179-188, Jul 2018.

ANTHONY, R. M.; RUTITZKY, L. I.; URBAN, J. F.; STADECKER, M. J. et al. Protective immune mechanisms in helminth infection. Nat Rev Immunol, 7, n. 12, p. 975-987, Dec 2007. 
ANTHONY, R. M.; URBAN, J. F.; ALEM, F.; HAMED, H. A. et al. Memory T(H)2 cells induce alternatively activated macrophages to mediate protection against nematode parasites. Nat Med, 12, n. 8, p. 955-960, Aug 2006.

AOKI, C. A.; BORCHERS, A. T.; RIDGWAY, W. M.; KEEN, C. L. et al. NOD mice and autoimmunity. Autoimmun Rev, 4, n. 6, p. 373-379, Jul 2005.

ASKENASY, N. Mechanisms of autoimmunity in the NOD mouse: effector/regulatory cell equilibrium during peak inflammation. Immunology, Jan 2016.

ATKINSON, M. A. Losing a grip on the notion of $\beta$-cell specificity for immune responses in type 1 diabetes: can we handle the truth? Diabetes, 63, n. 11, p. 3572-3574, Nov 2014.

ATKINSON, M. A.; EISENBARTH, G. S.; MICHELS, A. W. Type 1 diabetes. Lancet, 383, n. 9911, p. 69-82, Jan 2014.

BERBUDI, A.; AJENDRA, J.; WARDANI, A. P.; HOERAUF, A. et al. Parasitic helminths and their beneficial impact on type 1 and type 2 diabetes. Diabetes Metab Res Rev, 32, n. 3, p. 238-250, Mar 2016.

CANÇADO, G. G.; FIUZA, J. A.; DE PAIVA, N. C.; LEMOS, L. E. C. et al. Hookworm products ameliorate dextran sodium sulfate-induced colitis in BALB/c mice. Inflamm Bowel Dis, 17, n. 11, p. 2275-2286, Nov 2011.

CLARK, M.; KROGER, C. J.; TISCH, R. M. Type 1 Diabetes: A Chronic Anti-Self-Inflammatory Response. Front Immunol, 8, p. 1898, 2017.

COPPIETERS, K. T.; VON HERRATH, M. G. Histopathology of type 1 diabetes: old paradigms and new insights. Rev Diabet Stud, 6, n. 2, p. 85-96, 2009.

CROESE, J.; O'NEIL, J.; MASSON, J.; COOKE, S. et al. A proof of concept study establishing Necator americanus in Crohn's patients and reservoir donors. Gut, 55, n. 1, p. 136-137, Jan 2006.

DEJACO, C.; DUFTNER, C.; GRUBECK-LOEBENSTEIN, B.; SCHIRMER, M. Imbalance of regulatory T cells in human autoimmune diseases. Immunology, 117, n. 3, p. 289-300, Mar 2006.

DELOVITCH, T. L.; SINGH, B. The nonobese diabetic mouse as a model of autoimmune diabetes: immune dysregulation gets the NOD. Immunity, 7, n. 6, p. 727-738, Dec 1997.

EGRO, F. M. Why is type 1 diabetes increasing? J Mol Endocrinol, 51, n. 1, p. R1-13, 2013. 
ELLIOTT, D. E.; LI, J.; BLUM, A.; METWALI, A. et al. Exposure to schistosome eggs protects mice from TNBS-induced colitis. Am J Physiol Gastrointest Liver Physiol, 284, n. 3, p. G385-391, Mar 2003.

ELLIOTT, D. E.; SETIAWAN, T.; METWALI, A.; BLUM, A. et al. Heligmosomoides polygyrus inhibits established colitis in IL-10-deficient mice. Eur J Immunol, 34, n. 10, p. 2690-2698, Oct 2004.

ELLIOTT, D. E.; URBAN JF, J. R.; ARGO, C. K.; WEINSTOCK, J. V. Does the failure to acquire helminthic parasites predispose to Crohn's disease? FASEB J, 14, n. 12, p. 1848-1855, Sep 2000.

FERRETTI, C.; LA CAVA, A. Adaptive immune regulation in autoimmune diabetes. Autoimmun Rev, 15, n. 3, p. 236-241, Mar 2016.

FLEMING, J. O. Helminth therapy and multiple sclerosis. Int J Parasitol, 43, n. 3-4, p. 259-274, Mar 2013.

GAZE, S.; DRIGUEZ, P.; PEARSON, M. S.; MENDES, T. et al. An immunomics approach to schistosome antigen discovery: antibody signatures of naturally resistant and chronically infected individuals from endemic areas. PLoS Pathog, 10, n. 3, p. e1004033, Mar 2014.

GEIGER, S. M.; CALDAS, I. R.; MC GLONE, B. E.; CAMPI-AZEVEDO, A. C. et al. Stage-specific immune responses in human Necator americanus infection. Parasite Immunol, 29, n. 7, p. 347358, Jul 2007.

GRANGER, D. L.; TAINTOR, R. R.; BOOCKVAR, K. S.; HIBBS, J. B. Measurement of nitrate and nitrite in biological samples using nitrate reductase and Griess reaction. Methods Enzymol, 268, p. 142-151, 1996.

GRUDEN-MOVSESIJAN, A.; ILIC, N.; MOSTARICA-STOJKOVIC, M.; STOSIC-GRUJICIC, S. et al. Mechanisms of modulation of experimental autoimmune encephalomyelitis by chronic Trichinella spiralis infection in Dark Agouti rats. Parasite Immunol, 32, n. 6, p. 450-459, Jun 2010.

HARN, D. A.; MCDONALD, J.; ATOCHINA, O.; DA'DARA, A. A. Modulation of host immune responses by helminth glycans. Immunol Rev, 230, n. 1, p. 247-257, Jul 2009.

HÜBNER, M. P.; SHI, Y.; TORRERO, M. N.; MUELLER, E. et al. Helminth protection against autoimmune diabetes in nonobese diabetic mice is independent of a type 2 immune shift and requires TGF- $\beta$. J Immunol, 188, n. 2, p. 559-568, Jan 2012. 
HÜBNER, M. P.; STOCKER, J. T.; MITRE, E. Inhibition of type 1 diabetes in filaria-infected nonobese diabetic mice is associated with a T helper type 2 shift and induction of FoxP3+ regulatory T cells. Immunology, 127, n. 4, p. 512-522, Aug 2009.

IMAI, S.; TEZUKA, H.; FUJITA, K. A factor of inducing IgE from a filarial parasite prevents insulindependent diabetes mellitus in nonobese diabetic mice. Biochem Biophys Res Commun, 286, n. 5, p. 1051-1058, Sep 2001.

KAHALY, G. J.; HANSEN, M. P. Type 1 diabetes associated autoimmunity. Autoimmun Rev, 15, n. 7, p. 644-648, Jul 2016.

KAMINITZ, A.; MIZRAHI, K.; ASKENASY, N. Surge in regulatory T cells does not prevent onset of hyperglycemia in NOD mice: immune profiles do not correlate with disease severity.

Autoimmunity, 47, n. 2, p. 105-112, Mar 2014.

KHAN, W. I.; BLENNERHASSET, P. A.; VARGHESE, A. K.; CHOWDHURY, S. K. et al. Intestinal nematode infection ameliorates experimental colitis in mice. Infect Immun, 70, n. 11, p. 59315937, Nov 2002.

KING, C.; ILIC, A.; KOELSCH, K.; SARVETNICK, N. Homeostatic expansion of T cells during immune insufficiency generates autoimmunity. Cell, 117, n. 2, p. 265-277, Apr 2004.

LEITER, E. H.; PROCHAZKA, M.; COLEMAN, D. L. The non-obese diabetic (NOD) mouse. Am J Pathol, 128, n. 2, p. 380-383, Aug 1987.

LIU, Q.; SUNDAR, K.; MISHRA, P. K.; MOUSAVI, G. et al. Helminth infection can reduce insulitis and type 1 diabetes through CD25- and IL-10-independent mechanisms. Infect Immun, 77, n. 12, p. 5347-5358, Dec 2009.

MCSORLEY, H. J.; HEWITSON, J. P.; MAIZELS, R. M. Immunomodulation by helminth parasites: defining mechanisms and mediators. Int J Parasitol, 43, n. 3-4, p. 301-310, Mar 2013.

MOTRAN, C. C.; SILVANE, L.; CHIAPELLO, L. S.; THEUMER, M. G. et al. Helminth Infections: Recognition and Modulation of the Immune Response by Innate Immune Cells. Front Immunol, 9, p. 664, 2018.

NAIR, M. G.; GALLAGHER, I. J.; TAYLOR, M. D.; LOKE, P. et al. Chitinase and Fizz family members are a generalized feature of nematode infection with selective upregulation of Ym1 and Fizz1 by antigen-presenting cells. Infect Immun, 73, n. 1, p. 385-394, Jan 2005.

OSADA, Y.; SHIMIZU, S.; KUMAGAI, T.; YAMADA, S. et al. Schistosoma mansoni infection reduces severity of collagen-induced arthritis via down-regulation of pro-inflammatory mediators. Int J Parasitol, 39, n. 4, p. 457-464, Mar 2009. 
REARDON, C.; SANCHEZ, A.; HOGABOAM, C. M.; MCKAY, D. M. Tapeworm infection reduces epithelial ion transport abnormalities in murine dextran sulfate sodium-induced colitis. Infect Immun, 69, n. 7, p. 4417-4423, Jul 2001.

REYES, J. L.; TERRAZAS, L. I. The divergent roles of alternatively activated macrophages in helminthic infections. Parasite Immunol, 29, n. 12, p. 609-619, Dec 2007.

RICHARDSON, S. J.; MORGAN, N. G.; FOULIS, A. K. Pancreatic pathology in type 1 diabetes mellitus. Endocr Pathol, 25, n. 1, p. 80-92, Mar 2014.

SAUNDERS, K. A.; RAINE, T.; COOKE, A.; LAWRENCE, C. E. Inhibition of autoimmune type 1 diabetes by gastrointestinal helminth infection. Infect Immun, 75, n. 1, p. 397-407, Jan 2007.

SMITH, P.; MANGAN, N. E.; WALSH, C. M.; FALLON, R. E. et al. Infection with a helminth parasite prevents experimental colitis via a macrophage-mediated mechanism. J Immunol, 178, n. 7, p. 4557-4566, Apr 2007.

SPENCER, L. A.; WELLER, P. F. Eosinophils and Th2 immunity: contemporary insights. Immunol Cell Biol, 88, n. 3, p. 250-256, 2010 Mar-Apr 2010.

SUMMERS, R. W.; ELLIOTT, D. E.; URBAN, J. F.; THOMPSON, R. et al. Trichuris suis therapy in Crohn's disease. Gut, 54, n. 1, p. 87-90, Jan 2005.

SUMMERS, R. W.; ELLIOTT, D. E.; URBAN, J. F.; THOMPSON, R. A. et al. Trichuris suis therapy for active ulcerative colitis: a randomized controlled trial. Gastroenterology, 128, n. 4, p. 825832, Apr 2005.

SUTTON, T. L.; ZHAO, A.; MADDEN, K. B.; ELFREY, J. E. et al. Anti-Inflammatory mechanisms of enteric Heligmosomoides polygyrus infection against trinitrobenzene sulfonic acid-induced colitis in a murine model. Infect Immun, 76, n. 10, p. 4772-4782, Oct 2008.

UKAH, T. K.; CATTIN-ROY, A. N.; CHEN, W.; MILLER, M. M. et al. On the Role IL-4/IL-13 Heteroreceptor Plays in Regulation of Type 1 Diabetes. J Immunol, 199, n. 3, p. 894-902, 08 2017.

WEBB, L. M.; TAIT WOJNO, E. D. The role of rare innate immune cells in Type 2 immune activation against parasitic helminths. Parasitology, 144, n. 10, p. 1288-1301, Sep 2017.

ZACCONE, P.; BURTON, O.; MILLER, N.; JONES, F. M. et al. Schistosoma mansoni egg antigens induce Treg that participate in diabetes prevention in NOD mice. Eur J Immunol, 39, n. 4, p. 1098-1107, Apr 2009. 
bioRxiv preprint doi: https://doi.org/10.1101/2020.03.03.975953; this version posted March 6, 2020. The copyright holder for this preprint (which was not certified by peer review) is the author/funder. All rights reserved. No reuse allowed without permission.

ZACCONE, P.; FEHÉRVÁRI, Z.; JONES, F. M.; SIDOBRE, S. et al. Schistosoma mansoni antigens modulate the activity of the innate immune response and prevent onset of type 1 diabetes. Eur J Immunol, 33, n. 5, p. 1439-1449, May 2003.

ZÓKA, A.; SOMOGYI, A.; FIRNEISZ, G. [Type 1 diabetes mellitus: most recent advances in its pathogenesis and treatment]. Orv Hetil, 153, n. 27, p. 1047-1056, Jul 2012. 


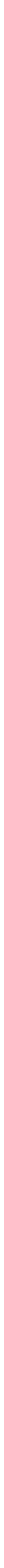


A

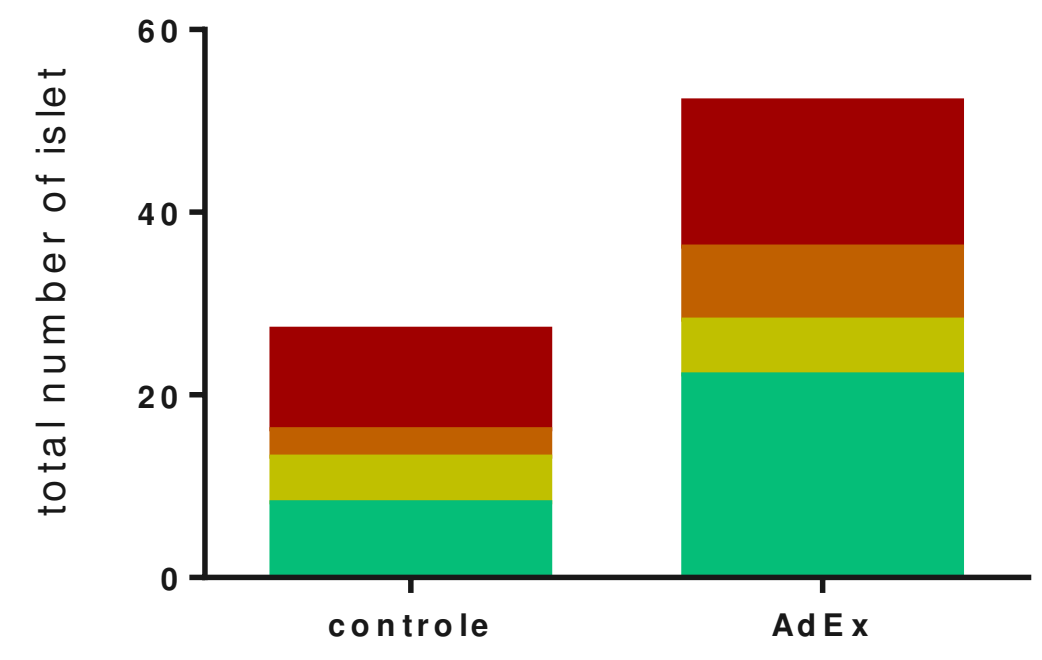

B

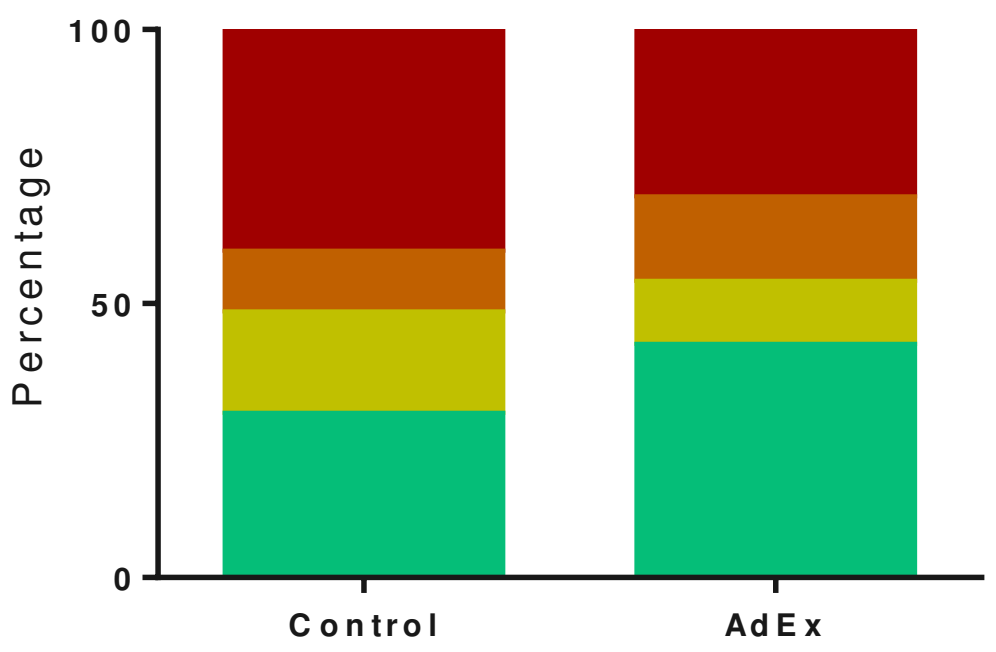

severe insulitis

moderate insulitis

perinsulitis

no insulitis 
Eosinophil

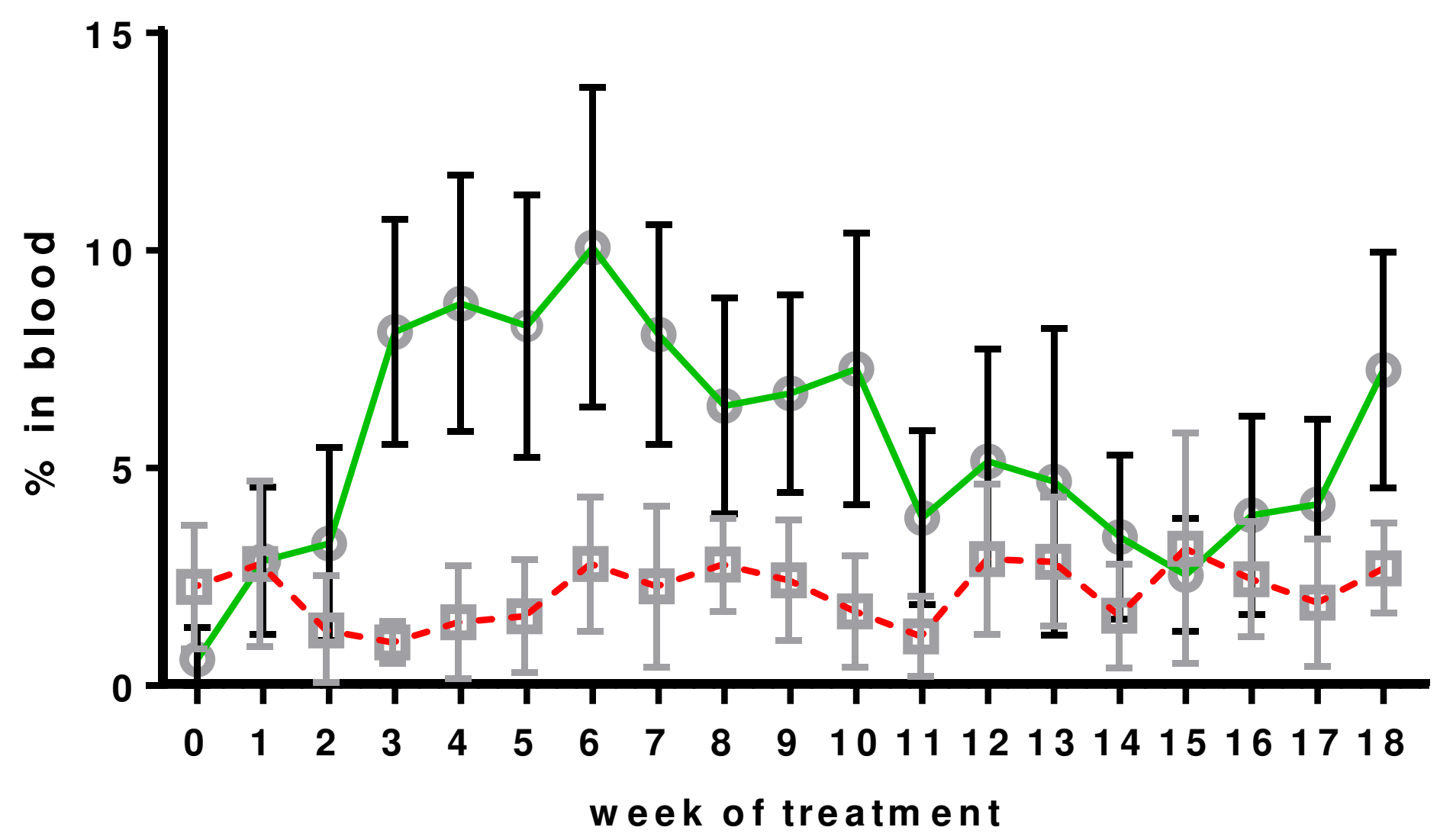



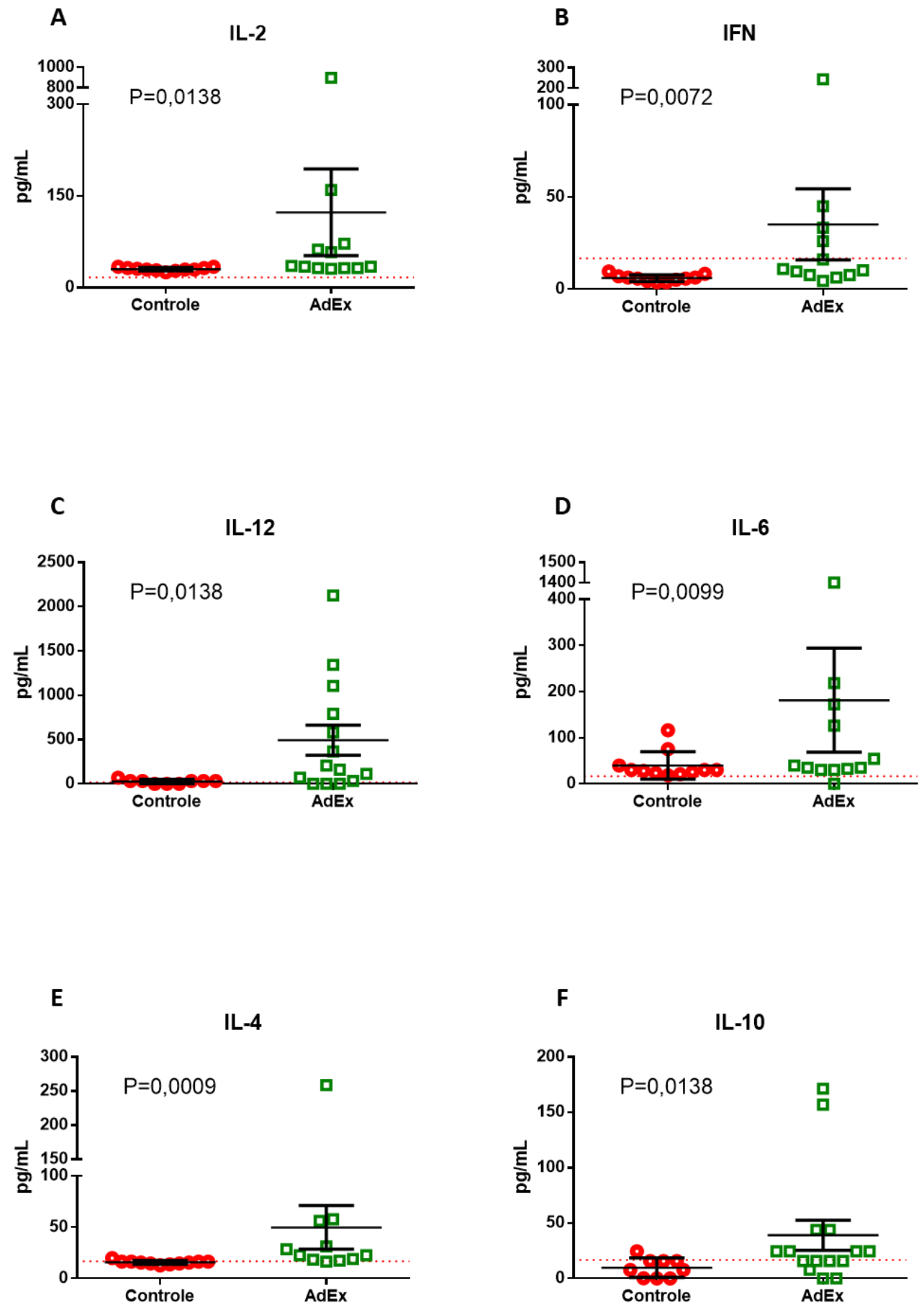

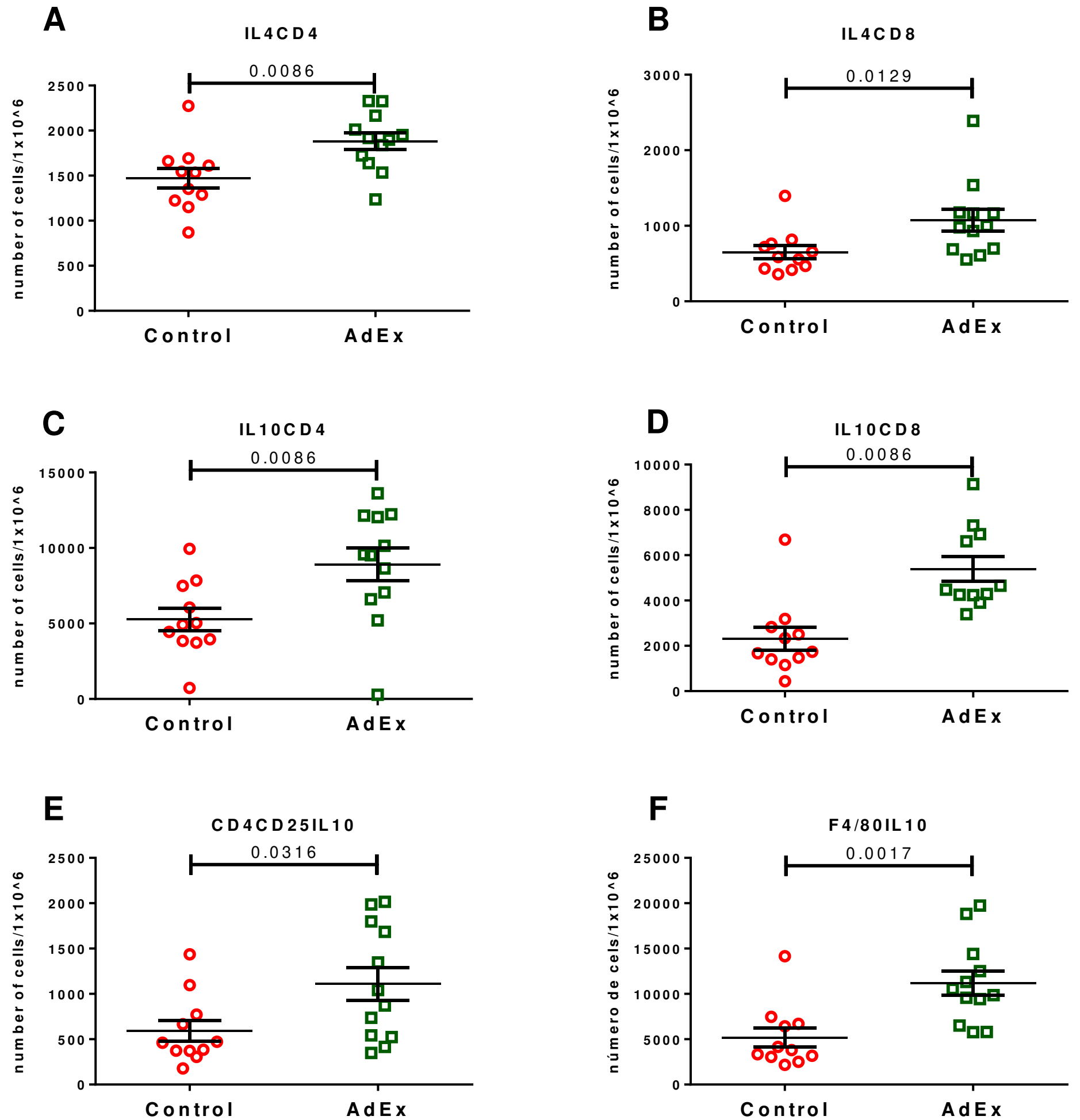
A

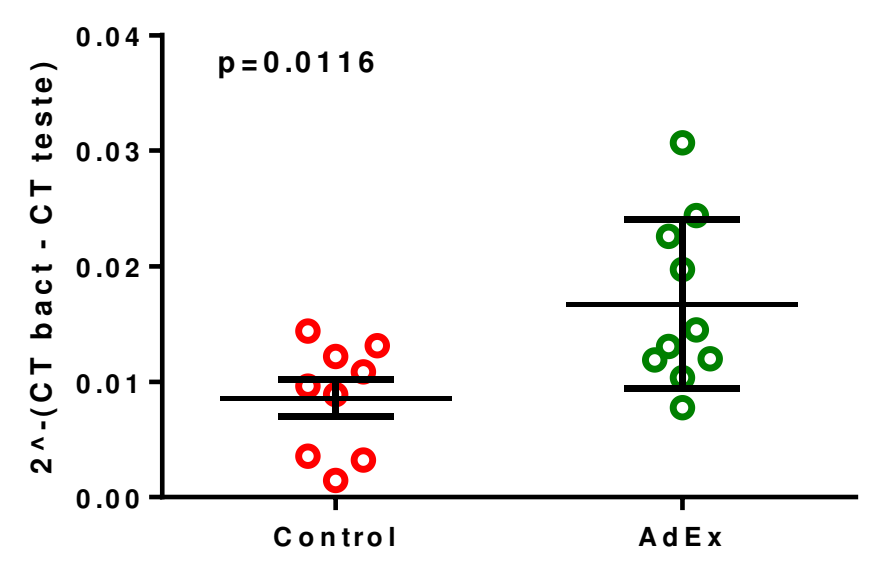

C

T G F

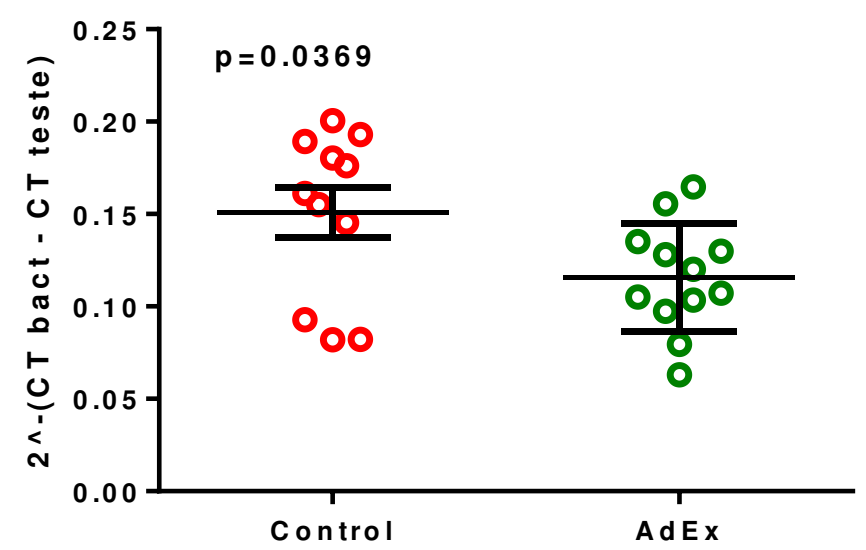

B

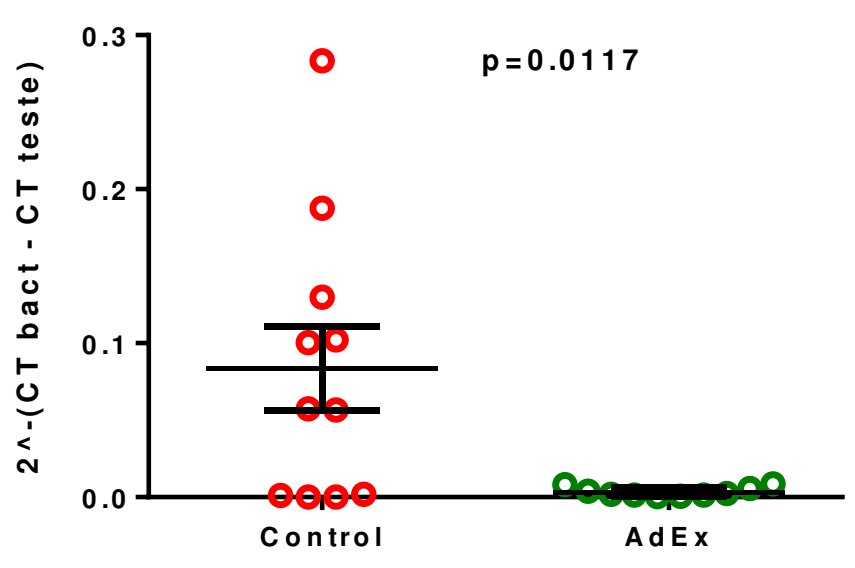

D

IL - 10

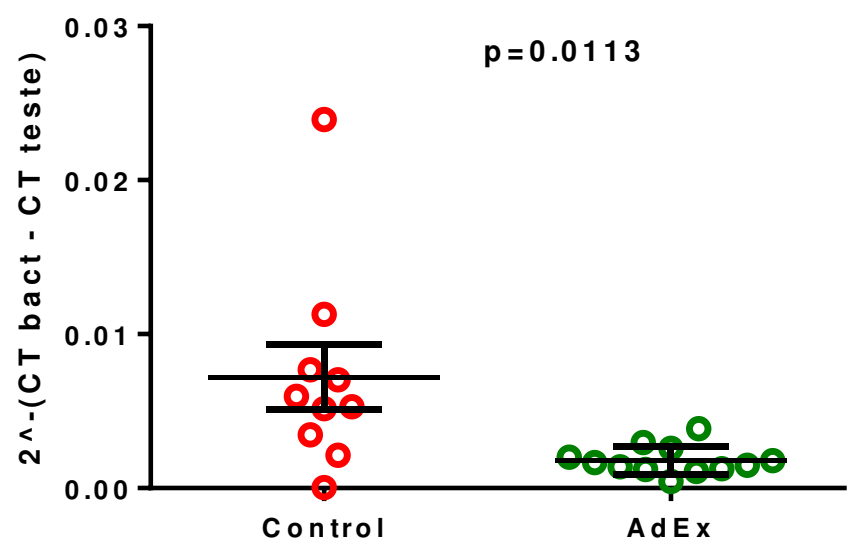


A

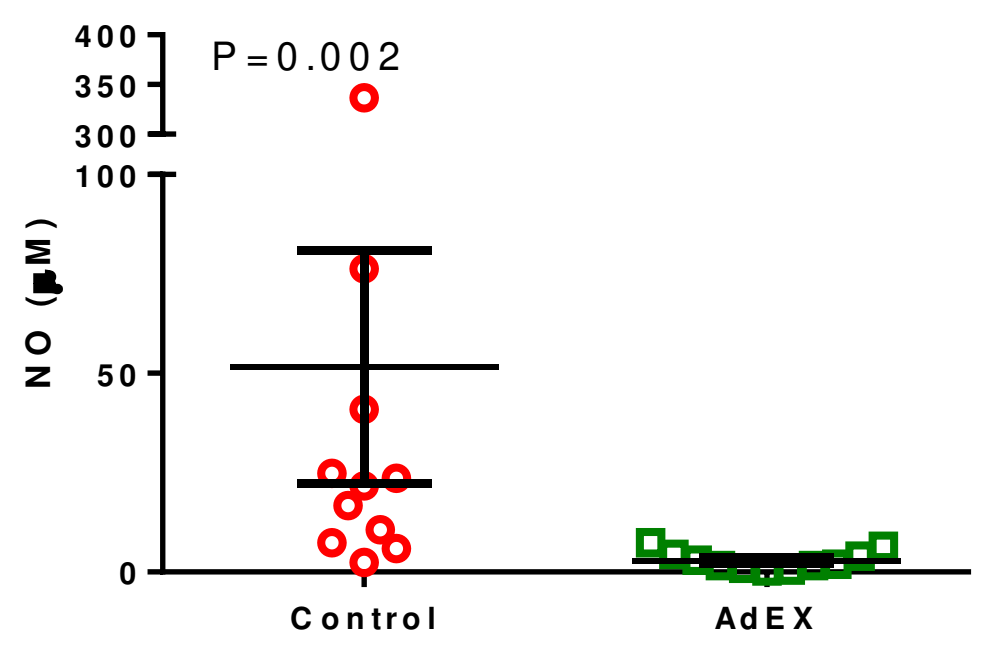

B

Supernatant

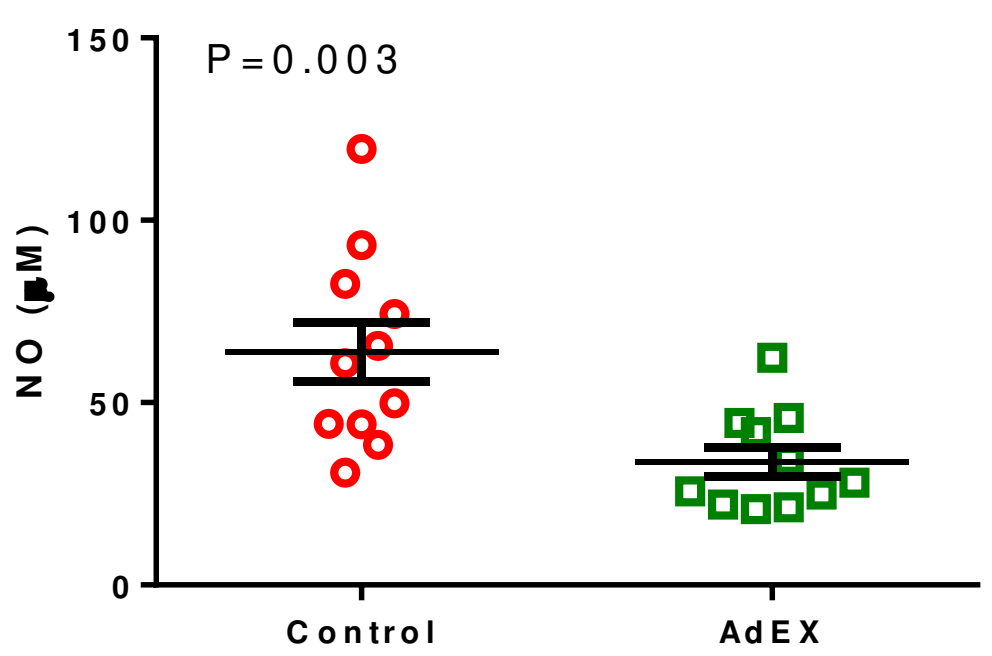



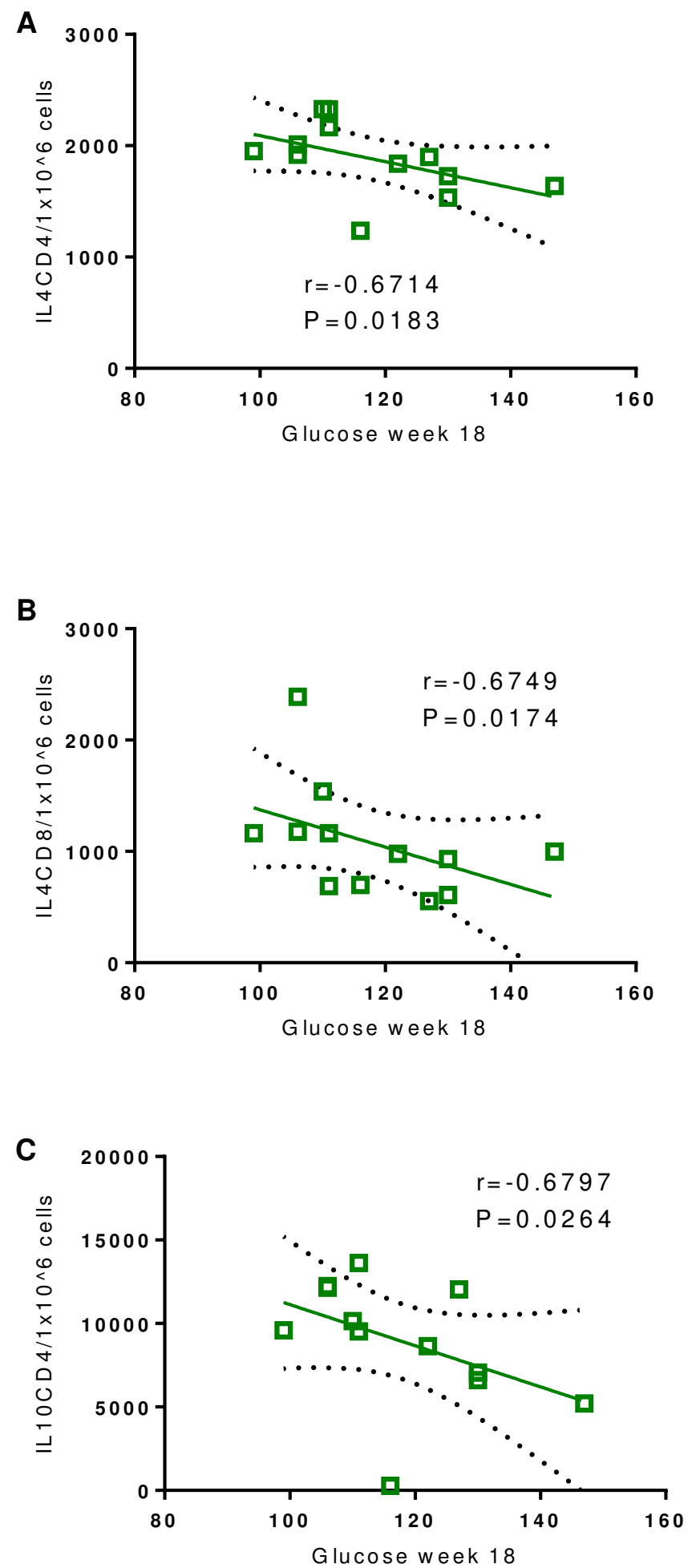